Ramírez-Moreno, F.J., Solís-Marín, F.A., \& LaguardaFigueras, A. (2021). Annotated checklist for the Gorgonocephalidae family (Echinodermata: Ophiuroidea) from the National Echinoderm Collection "Dra. Ma. E. Caso M." of the Instituto de Ciencias del Mar y Limnologia, UNAM. Revista de Biología Tropical, 69(S1), 287-303. DOI 10.15517/ rbt.v69iSuppl.1.46360

\title{
Annotated checklist for the Gorgonocephalidae family (Echinodermata: Ophiuroidea) from the National Echinoderm Collection "Dra. Ma. E. Caso M." of the Instituto de Ciencias del Mar y Limnología, UNAM
}

Frida Jacqueline Ramírez-Moreno ${ }^{1}$

Francisco Alonso Solís-Marín*2

Alfredo Laguarda-Figueras ${ }^{2}$

1. Facultad de Estudios Superiores Iztacala, Universidad Nacional Autónoma de Mexico. Mexico City, Mexico; fridajacqueline95@gmail.com

2. Colección Nacional de Equinodermos "Dra. Ma. E. Caso Muñoz", Laboratorio de Sistemática y Ecología de Equinodermos. Instituto de Ciencias del Mar y Limnología, Universidad Nacional Autónoma de México. Ciudad de México, México; fasolis@cmarl.unam.mx (*Correspondence), laguarda@cmarl.unam.mx

Received 02-II-2020. Corrected 12-IX-2020. Accepted 10-XII-2020.

\begin{abstract}
Introduction: The order Euryalida is represented by fragile ophiuroids with long and slender arms that can be ramified. Species within the family Gorgonocephalidae are characterized by the presence of tiny hooklets on the dorsal aspect of their arms. There are very few published studies referring to species of the family Gorgonocephalidae inhabiting Mexican waters. Objective: To review the taxonomic status of the species belonging to this taxonomic family, identifying their diagnostic taxonomic characteristics to create an illustrated guide of species kept at the CNE, UNAM. Methods: Specialized bibliography of the Gorgonocephalidae family was gathered. Subsequently, all the specimens from the CNE were photographed using Scanning Electron and Multifocal Microscopy photography, to show the structures of taxonomic relevance. Results: A total of 193 specimens corresponding to eight genera and nine species were reviewed. The genus Astrocaneum presented the highest species richness. Conclusions: For the species identified in this study and for the sake of accurate identification, morphological characters such as the shape of hooklets and arm plates were highlighted.
\end{abstract}

Keywords: Basket stars, taxonomy, biodiversity, deep-sea, Mexico.

Current classifications of the Ophiuroidea recognize two orders, the Euryalida (basket or snake stars) with 5 families, and the Ophiurida (brittle-stars) with 15 families (O'Hara, Hugall, Thuy, Stöhr and Martynov, 2018). Even though the order Euryalida is widely distributed the specimens are not easy to capture since many live in the deep sea and display cryptic behaviors (Hyman, 1955). Most of the species are epizoic and are found among gorgonians, antipatharians, and sponges. They are occasionally associated with hard substrates (Gondim, Dias \& Manso, 2012). The members of this order possess specialized morphological attributes of the class Ophiuroidea, including the presence of vertebrae with 
hourglass-shaped joints (of the streptospondylous type) that allow them to move their arms vertically (Hendler and Miller, 1984).

The Gorgonocephalidae is conformed by 34 genera and is the largest of the three families integrating the order Euryalida (Stöhr, 2015). The species in this family have five intricately branched arms, with rings that have few hookshaped spines, giving them a banded appearance (Piepenburg, 2000). The disc and the arms in this genus are covered by small granules, except on the interradios (Baker, 1980). There are studies addressing specimens of this family, like O'Hara, Hugall, Thuy, Stöhr \& Martynov (2018) who reported a new classification with the morphological diagnosis of the Ophiuroidea taxa. However, the studies referring to species of the family Gorgonocephalidae inhabiting Mexican waters are scarce. An example is the work published by Solís-Marín and collaborators (2014) in which they only present a list of echinoderm species found in Mexican waters with no further analysis or description.

This study will bring together important and specific information of some gorgonocephalid species, the species under consideration are distributed along the Pacific and Atlantic coasts of Mexico, which are home to important reef systems. The taxonomic information on this family has been scarce in comparison with other ophiuroid groups.

\section{MATERIALS AND METHODS}

Using the specialized library incorporated in the Laboratory of Echinoderm Systematics and Ecology (LESE, UNAM), some literature specialized in the family Gorgonocephalidae was gathered. Specimens described herein have been cataloged and deposited at the Echinoderm National Collection "Dra. Ma. Elena
Caso M.". Materials were collected in the Pacific and Atlantic Oceans between 1964 and 2007 through multiple expeditions (Table 1). These specimens were preserved dry and in 70 $\%$ alcohol. The materials were examined using an OLYMPUS SZX7 stereoscopic microscope and pictures were taken using a Leica stereoscopic microscope at the Biology Institute (BI), UNAM. Some specimens were dissected to analyze and photograph their internal structures, using Scanning Electron Microscopy (SEM) JEOL JSM-6360 LV at ICML, UNAM. The fragments were immersed in commercial house bleach, and then a $5 \% \mathrm{NaCIO}$ solution to remove muscle tissue. Finally, the mounting was performed in an aluminum sample holder and carbon labels for SEM. Finally, the photographs of the taxonomically important structures used for species identification were edited using Adobe Photoshop CC and were edited to add scales and group all the photographs.

The taxonomic terms used to describe the euryalid brittle stars in this work follow Stöhr, O'Hara, and Thuy (2012) and Okanishi (2016). The taxonomic arrangement was made according to O'Hara et al. (2018).

Abbreviations used in this work: Colección Nacional de Equinodermos, CNE. Universidad Nacional Autónoma de México, UNAM.

\section{RESULTS}

A total of 193 specimens were examined, belonging to eight genera and nine species, with a bathymetric distribution from 73 to $201 \mathrm{~m}$. The genus with the highest species richness in the CNE, UNAM was Astrocaneum (two species) and the ones with less specific richness were Asteroporpa, Astrodictyum, Astracme, Astrocyclus, Astrogomphus, Astrophyton, and Gorgonocephalus (with one species each).

\section{Taxonomic synopsis}

Class Ophiuroidea Gray, 1840

Order Euryalida Lamarck, 1816

Family Gorgonocephalidae Ljungman, 1867

Genus Asteroporpa Örstedt \& Lütken, 1856 in Lütken, 1856 
TABLE 1

Species of the family Gorgonocephalidae reviewed at the Colección Nacional de Equinodermos, Instituto de Ciencias del Mar y Limnología, UNAM

\begin{tabular}{|c|c|c|c|}
\hline $\begin{array}{c}\text { No. of } \\
\text { specimens }\end{array}$ & Locality & Depth & Preservation condition \\
\hline \multicolumn{4}{|c|}{ Asteroporpa (Asteroporpa) annulata (Örstedt \& Lütken 1856, in Lütken, 1856) } \\
\hline 23 & North of Olbox, Quintana Roo. & $69.2-730 \mathrm{~m}$ & Alcohol \\
\hline 1 & North of Cabo Catoche, Quintana Roo. & $57.5 \mathrm{~m}$ & Dry \\
\hline \multicolumn{4}{|c|}{ Astracme mucronata (Lyman, 1869) } \\
\hline 5 & North Atlantic Ocean, Bahamas, Yucatan Mexico. & $305-400 \mathrm{~m}$ & Alcohol \\
\hline 3 & North of Progreso, Yucatan, Mexico. & $336 \mathrm{~m}$ & Dry \\
\hline \multicolumn{4}{|c|}{ Astrocaneum herrerai (Clark, 1919) } \\
\hline 2 & Franco de Contoy, Quintana Roo. & $38 \mathrm{~m}$ & Dry \\
\hline \multicolumn{4}{|c|}{ Astrocaneum spinosum (Lyman, 1875) } \\
\hline 1 & Bajo Marisal, Gulf of California. & $40 \mathrm{~m}$ & Alcohol \\
\hline 1 & Las Ánimas Island, Gulf of California. & $60 \mathrm{~m}$ & Dry \\
\hline \multicolumn{4}{|c|}{ Astrocyclus caecilia (Lütken, 1856) } \\
\hline 2 & Gulf of Mexico. & $87-116 m$ & Alcohol \\
\hline \multicolumn{4}{|c|}{ Astrodictyum cf. panamense (Verrill, 1867) } \\
\hline 5 & The Gulf of California. & $30-60 m$ & Alcohol \\
\hline 12 & Baja California and Oaxaca. & $30-40 \mathrm{~m}$ & Dry \\
\hline \multicolumn{4}{|c|}{ Astrogomphus vallatus (Lyman, 1869) } \\
\hline 1 & Off Río Lagartos, Campeche’s Bank. & $215 \mathrm{~m}$ & Alcohol \\
\hline \multicolumn{4}{|c|}{ Astrophyton muricatum (Lamarck, 1816) } \\
\hline 16 & Contoy Island, Quintana Roo. & $33 \mathrm{~m}$ & Alcohol \\
\hline 20 & Contoy Island, Quintana Roo. & $15-57 \mathrm{~m}$ & Dry \\
\hline \multicolumn{4}{|c|}{ Gorgonocephalus chilensis (Philippi, 1858) } \\
\hline 1 & Puerto Santa Cruz, Bahía Grande, South Atlantic Ocean. & $50 \mathrm{~m}$ & Alcohol \\
\hline
\end{tabular}

Asteroporpa (Asteroporpa) annulata (Örstedt \& Lütken, 1856 in Lütken, 1856)

Genus Astracme Döderlein, 1927

Astracme mucronata (Lyman, 1869)

Genus Astrocaneum Döderlein, 1911

Astrocaneum herrerai (Clark, 1919)

Astrocaneum spinosum (Lyman, 1875)

Genus Astrocyclus Döderlein, 1911

Astrocyclus caecilia (Lütken, 1856)

Genus Astrodictyum Döderlein, 1927

Astrodictyum panamense (Verrill, 1867)

Genus Astrogomphus Lyman, 1869

Astrogomphus vallatus (Lyman, 1869)

Genus Astrophyton Fleming, 1828

Astrophyton muricatum (Lamarck, 1816)

Genus Gorgonocephalus Leach, 1815

Gorgonocephalus chilensis (Philippi, 1858) 
Order Euryalida Lamarck, 1816

Diagnosis (O'Hara et al., 2018): arm spine articulations with muscle and nerve openings well separated. Arm spines ventral only. Lateral arm plates devoid of ornamentation. Vertebrae with hourglass-shaped articulations.

Family Gorgonocephalidae Ljungman, 1867

Diagnosis (O'Hara et al., 2018): dorsal part of the disc and arms with scales and plates, which bear thorny granules or spines. In the arms, they present Girdles of small hyaline hooks. Arms branched or simple. All vertebrae without an oral bridge. Multiple teeth in irregular columns, dental plate whole. Arm spine articulation with slit-shaped muscle opening proximally bordered by a vertical ridge, small nerve opening at a distance.

Genus Asteroporpa Örsted \& Lütken 1856, in Lütken, 1856

Diagnosis (Örstedt \& Lütken, 1856 in Lütken, 1856): disc with 10 short radial shields and five arms, extremely long and tightly articulated arms that are very narrow at their ventral side. Both radial shields are elevated from the arm region and covered by skin with warts and articulated hooks. Along the borders of the mouth, they exhibit sharp cone-shaped papillae. They have short hooklets underneath the arm rings.

\section{Asteroporpa (Asteroporpa) annulata}

(Örstedt and Lütken, 1856 in Lütken, 1856)

Fig. 1A, 1B, 1C, 1D, Fig. 6A, 6B.

\section{Asteroporpa (Asteroporpa) annulata} Örstedt \& Lütken, 1856 in Lütken, 1856: 17, Figs. 4a-d, 5a-b; Lyman, 1883: 125; Verrill, 1899 (b): 320; Döderlein, 1911: 24, Fig. 2a-f; Döderlein 1927: 89; Gondim et al., 2012: 142145, Fig. 1.

Diagnosis (Gondim et al., 2012): aboral part of the disk covered by a thick skin, the radial shields and their surrounding are tumid, bar-like, extending more than half of the disk diameter, and covered by five rows of rings with sharp granules. The jaws and oral parts are covered by a thick skin and show small, flattened dermal ossicles. There are five simple arms; the dorsal and lateral surfaces of the arms are annulated, with inflated, white, and transverse rows of hooklet-bearing plates.

Scanning Electron Microscopy: Asteroporpa (Asteroporpa) annulata can be distinguished by its type of spines, which no other organism possesses. These spines have a rectangular base with five to seven spikes, the hooklets have an open and marked base, with clear edges; there are six very noticeable perforations found along the hooklet, at the secondary tooth base there is a groove, and the main hooklet is long (Fig. 6A, 6B).

\section{Genus Astracme Döderlein, 1927}

Diagnosis (Döderlein, 1927): disc and arms with thick spines, one madreporite; the first section of the arms exhibits many ramifications. They exhibit small tentacle pores before the first bifurcation; from one to three arm spines (small-sized), beginning before or immediately after the first arm bifurcation; all the final bifurcation are thin, with hooks and well-developed hook rows.

\section{Astracme mucronata (Lyman, 1869)}

Fig. 2A, 2B, 2C, 2D, Fig. 6D, 6H.

Astrophyton mucronatum Lyman, 1869: 348. Gorgonocephalus mucronatus Lyman, 1882: 265; Verrill, 1899: 85. Astrospartus mucronatus Döderlein, 1911: 73. Astracme mucronata Döderlein, 1927: 31.

Diagnosis (Manso, Gondim, \& Ventura, 2014): disc covered by flattened plate-shaped dermal ossicles of varied sizes and shapes, and some granules. Large radial shields, barlike, covered flattened by plate-shaped dermal ossicles and some granules and spines; there are irregularly distributed spine-shaped dermal ossicles on the radial shield, the interradius is covered by flattened, plate-shaped dermal 
ossicles and some spine-shaped ossicles (similar to the radial shields). The jaw and oral part are covered with granules larger than those on the dorsal surface.

Scanning Electron Microscopy: Astracme mucronata has spines at the radial shields, which have a flat point and a narrow base (Fig. $6 \mathrm{C}$ ). It has three different types of hooklets; there are marked differences at the base of each type of hooklet and also in the shape of it, having one and two secondary teeth (Fig. 6F, 6G, 6H).

\section{Genus Astrocaneum Döderlein, 1911}

Diagnosis (Döderlein, 1911): disc and arms with protuberances or thicker spines. Five madreporites. The main internal and external arm branching is lightly extended, the distal ramifications are thin, thread-shaped and the lateral ramifications are cone-shaped. The spine-shaped papillae are found along the arms, are tiny, and are observable from the third or fourth bifurcation.

\section{Astrocaneum herrerai (Clark, 1919)}

Fig. 2E, 2F, 2G, 2H, Fig. 6I, 6J.

Astrocynodus herrerai A.H. Clark, 1919: 638, Fig. 96. Astrocaneum herrerai.- Döderlein, 1927: 56; Durán-González, Laguarda-Figueras, Solís-Marín, Buitrón-Sánchez, Ahearn, \& Torres-Vega, 2005: 5; Pomory, 2007: 3.

Diagnosis (Clark, 1919): the oral side of the disc is covered by small granules, at the external half of the radial shields present crossed bands that are divided into sections and can be found diagonally across the shield. At the interradial oral side of the disc, it is covered with very small granules, among which there are bigger and brighter granules, grouped in a way that they form a mesh-like pattern.

Astrocaneum spinosum (Lyman, 1875)

Fig. 3A, 3B, 3C, 3D, Fig. 6K, 6L, 6M.

Astrophyton spinosum Lyman, 1875: 29. Astrocaneum spinosum.- Döderlein, 1911: 92;
Döderlein, 1927: 55; Béarez \& Bujard, 2013: 2, Figs. 2-3.

Diagnosis (Lyman, 1875): at the aboral side of the disc they have a small row of spines that are scattered in groups of two or three, at the internal angle of each of the oral interradial spaces there is a madreporite; there are no signs of arm spines close to the base of the arm, but they appear at the fifth ramification, where there are two to three arm spines per each pore; the tentacle pores are narrowly contracted.

Scanning Electron Microscopy: The genus Astrocaneum posses oblong spines, however, between $A$. herrerai and $A$. spinosum there are differences at the tip of the hooklet; A. spinosum has a flat tip and is located at the center of the hooklet (Fig. 6L). The hooklets are the main characteristic to differentiate all species, which is why between these species ( $A$. herrerai and $A$. spinosum) there is a morphological difference at the base of the hooklet, been longer with a bulky protruding base in $A$. herrerai (Fig. 6J).

\section{Genus Astrocyclus Döderlein, 1911}

Diagnosis (Döderlein, 1911): the radial shields and arms show prominent transversal bulges and slightly ramified arms. Five madreporites at the interior edge of the oral interradius, the tentacle pores are small and appear before or immediately after the first bifurcation. Each hook of the belt posses one or two secondary teeth; the arm spines are hook-shaped, they present one to two secondary teeth.

Astrocyclus caecilia (Lütken, 1856)

Fig. 3E, 3F, 3G, 3H, Fig. 6N, $6 \mathrm{O}$.

Asterophyton caecilia Lütken, 1856: 18; Lyman, 1882: 258.

Astrocyclus caecilia.- Tommasi, 1970: 13; Gondim et al., 2015: 2, Fig. 1.

Diagnosis (Tommasi, 1970): slightly elevated radial shields, without spines or tubercules, only transversal lines; at the center of the disc there are big, protruding, and elongated 


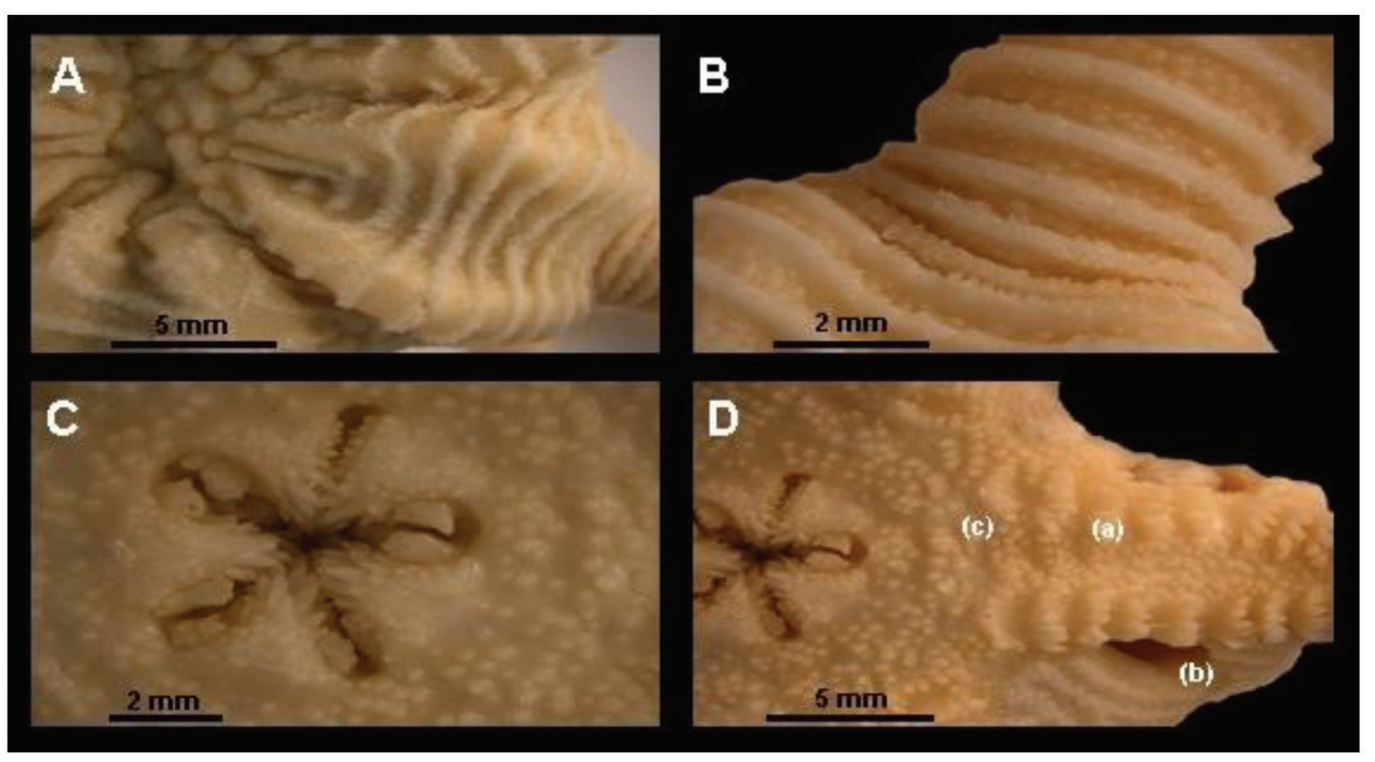

Fig. 1. Asteroporpa (Asteroporpa) annulata (ICML-UNAM 3.120.1). A. Ventral aspect of the central region of the disc showing the rings over the radial shields. B. Dorsal aspect of the basal portion of the arm showing the ring. C. Mouth. D. Ventral aspect of the basal portion of the arm. (a). Arms spines (b). Bursal slit (c). Granules.

granules. Five madreporites, each one located in an internal angle of the interradial spaces. The arms at the oral side exhibit a small and truncated arm spine, at the tip of the arms, the arm spine transforming into hook-shaped.

\section{Genus Astrodictyum Döderlein, 1927}

Diagnosis (Döderlein, 1927): the disc and arms exhibit bulges or thick spines; the main ramification of arms is slightly extended, the distal ramifications are thin and feather-shaped. There are five madreporites, the arm spines are uniformly found along the arms, they are small and begin at a certain distance from the disc, not before the third or fourth bifurcation.

\section{Astrodictyum cf. panamense (Verrill, 1867)}

Fig. 4A, 4B, 4C, 4D, Fig. 7A, 7B, 7C.

Astrophyton panamense Verrill, 1867: 251. Astrocaneum panamense.- Döderlein, 1911: 95.

Diagnosis (Verrill, 1867): the oral and aboral surfaces are covered by rough granules, at the radial shields and the dorsal side of the arms the granules are round and uniform in size, but on the ventral side they are flattened and larger. The aboral surface is slightly convex and has no presence of spines or tubercules. From two to three tentacle pores that are noted for being short, which begin at the third or fourth bifurcation; they exhibit small hooks, visible only at the terminal ramifications.

\section{Genus Astrogomphus Lyman, 1869}

Diagnosis (Lyman, 1869): radial shields narrow and short, the peripheral part presents numerous spines. Simple arms, the skin is covered by a mosaic of small granules, the segments of the arms are distinguished for having ridges, each one formed by a belt of granules, some of which are very small. The arm spines have the shape of a thorny stump, arranged in groups just above the tentacle pores.

Astrogomphus vallatus Lyman, 1869

Fig. 4E, 4H, Fig. 7D, 7E, 7F, 7G.

Astrogomphus vallatus Lyman, 1869: 350; Durán-González et al., 2005: 59. 

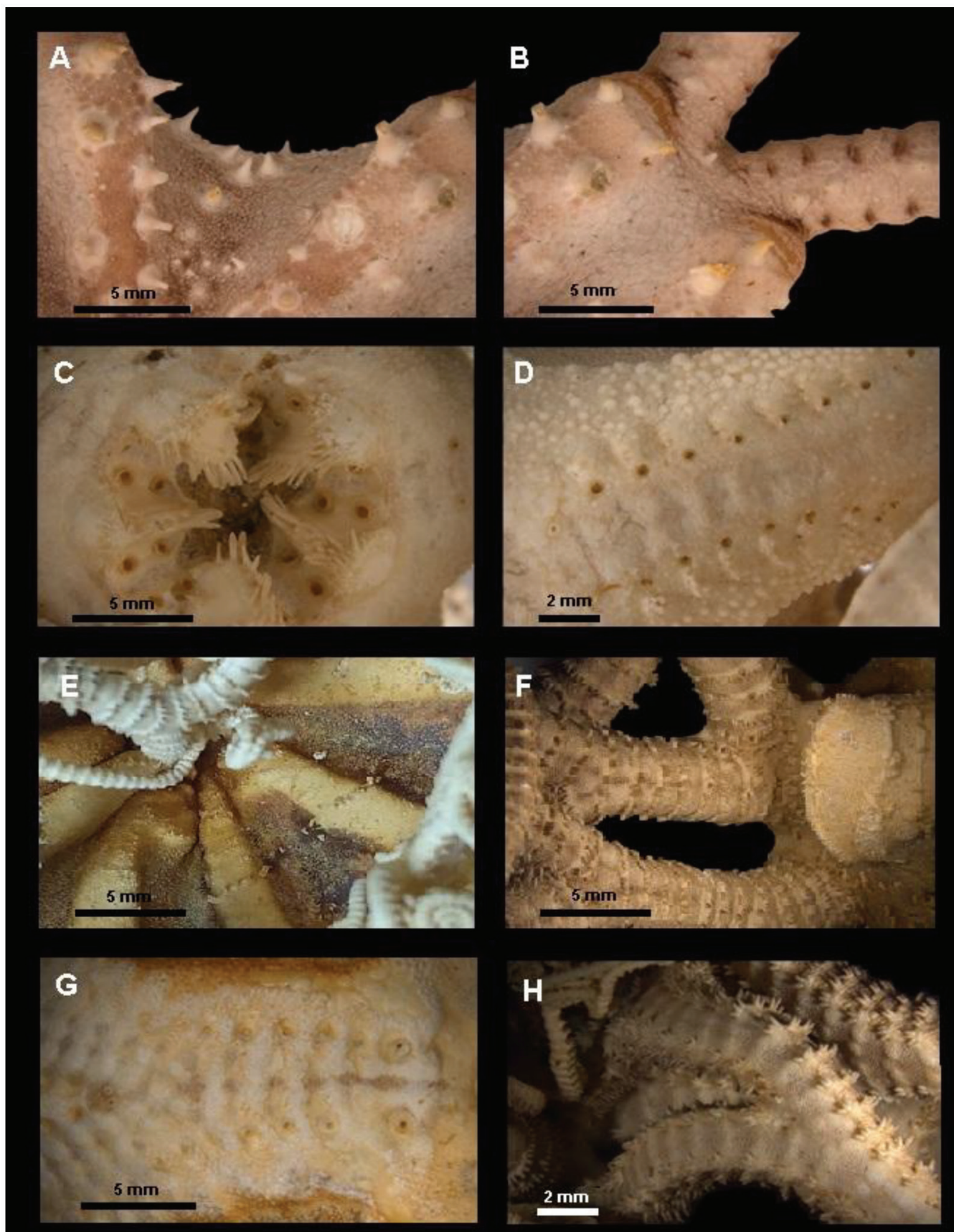

Fig. 2. Astracme mucronata (ICML-UNAM, 12308). A. detail of the interradi zone with conical spines. B. Distal region of the radial shields showing a small notch at their base and first fork of the arm. C. Mouth. D. Ventral view of the arm showing the tentacular pores. Astrocaneum herrerai (ICML-UNAM 3.118.15), E. Detail of the spines arranged in-band over radial shields. F. Radial shields showing a small notch at their base, arm with bands of spines similar to those of the disc. G. Detail of the tentacular pores at the first bifurcation. H. Arm spines after the third fork. 


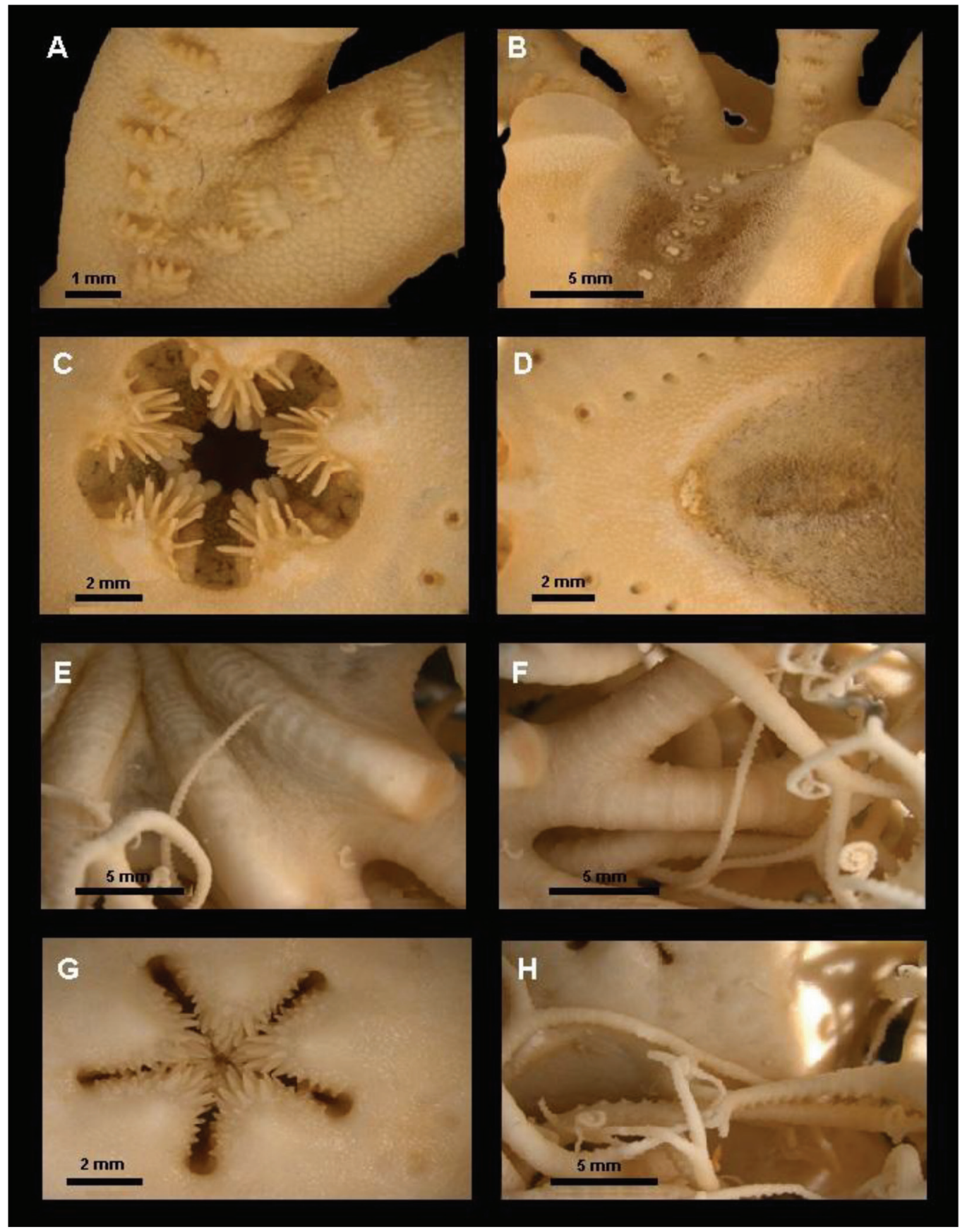

Fig. 3. Astrocaneum spinosum (ICML-UNAM 9821), A. Series of six spines on the arms. B. Dorsal view of the base of the disc and the arms. C. Mouth. D. Detail of the madreporite and tentacular pores. Astrocyclus caecilia (ICML-UNAM 3.184.1). E. Detail view of the radial shields. F. Dorsal view of the proximal portion of the arm. G. Mouth. H. Distal ramifications. 


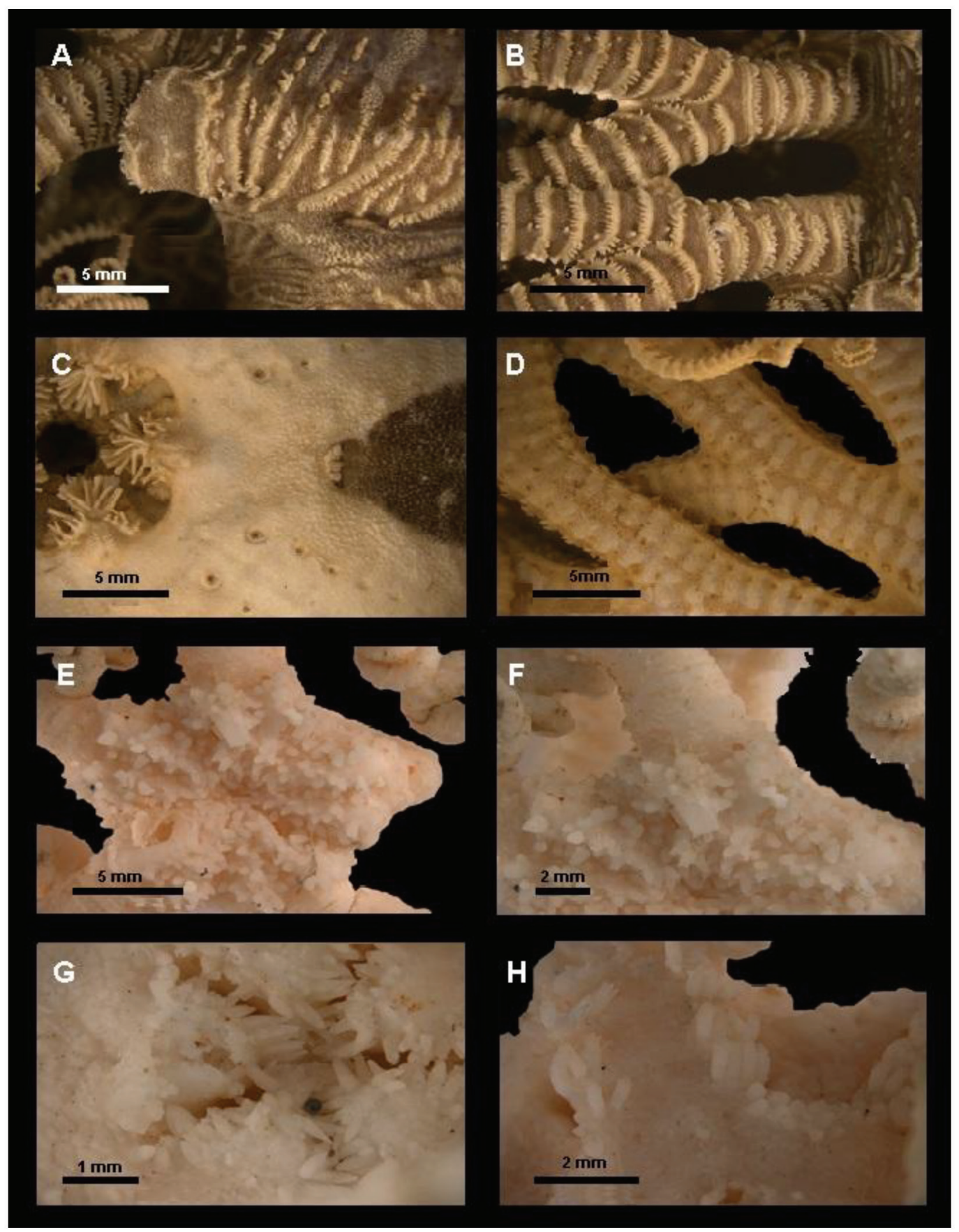

Fig. 4. Astrodictyum cf. panamense (ICML-UNAM 9822). A. Radial shield with a transverse notch. B. Dorsal view of the branching base of the arms. C. Tentacular pores. D. Ventral view of the arms. Astrogomphus vallatus (ICML-UNAM 3.165.0). E. Aboral views of the disc. F. Arm base and disk periphery. G. Mouth. H. Arm spines from basal arm segments. 


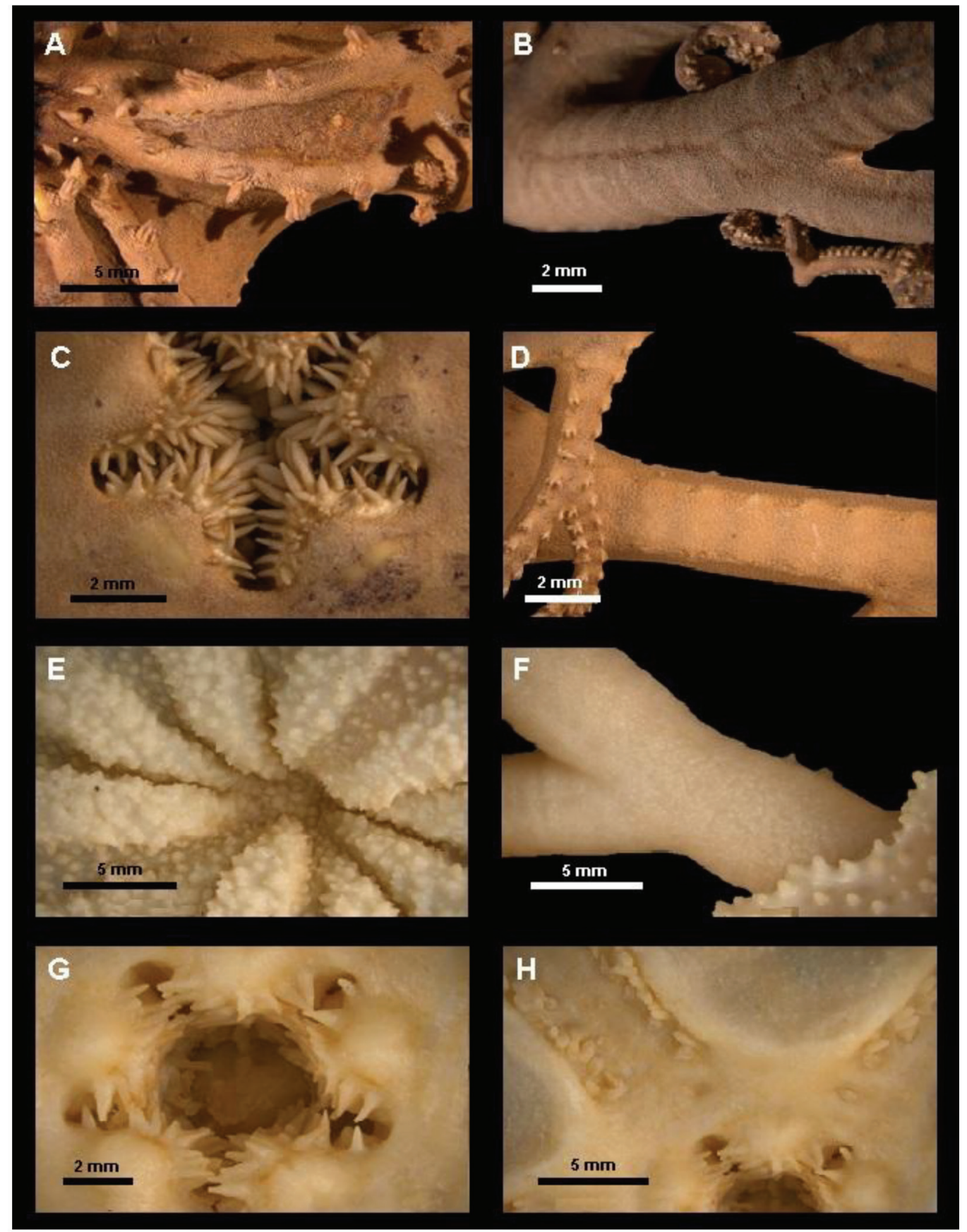

Fig. 5. Astrophyton muricatum (ICML-UNAM 3.165.0). A. detail of the radial shields. B. Dorsal view of the basal arm segments. C. Mouth. D. Dorsal and ventral view of the distal portion of the arm. Gorgonocephalus chilensis (ICML-UNAM 3.239.0). E. Partial view of the radial shields and the central region of the disc. F. Basal portion of the arm. G. Mouth. H. Arm spines that extends into the oral disc. 


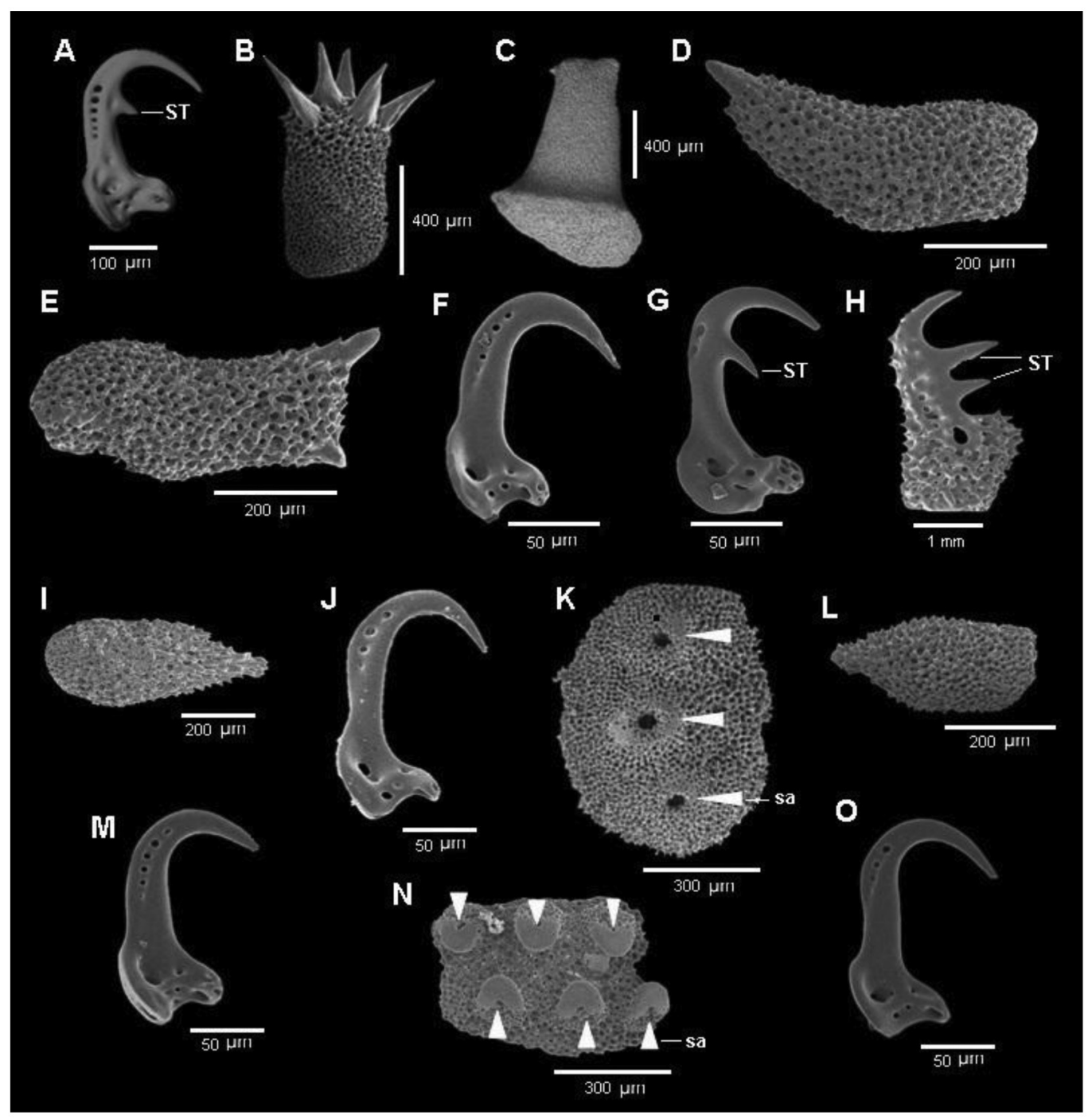

Fig. 6. SEM photographs of arm spines, hooks, and hooklet-bearing plates of different species of Gorgonocephalidae housed at ICML. Asteroporpa (Asteroporpa) annulata (ICML-UNAM 30120.1). A. Hook on distal arm. B. Arm spine of the middle portion of the arm. Astracme mucronata (ICML-UNAM 12308). C. Arm spine. D-E. Arm spine of the middle portion of the arm. F. Hook located in the middle part of an arm. G-H. Hook on the distal portion of an arm. Astrocaneum herrerai (ICMLUNAM 3.118.15). I. Arm spines. J. Simple hooks distributed along the arms. Astrocaneum spinosum (ICML-UNAM 9821). K. External structures: hooklet-bearing plate. L. Arm spine. M. Hook of the arm. Astrocyclus caecilia (ICML-UNAM 3.184.1). N. Hooklet-bearing plate. O. Hook of the arms. Abbreviations: ST. Secondary tooth. sa, Arm spine articulation. 


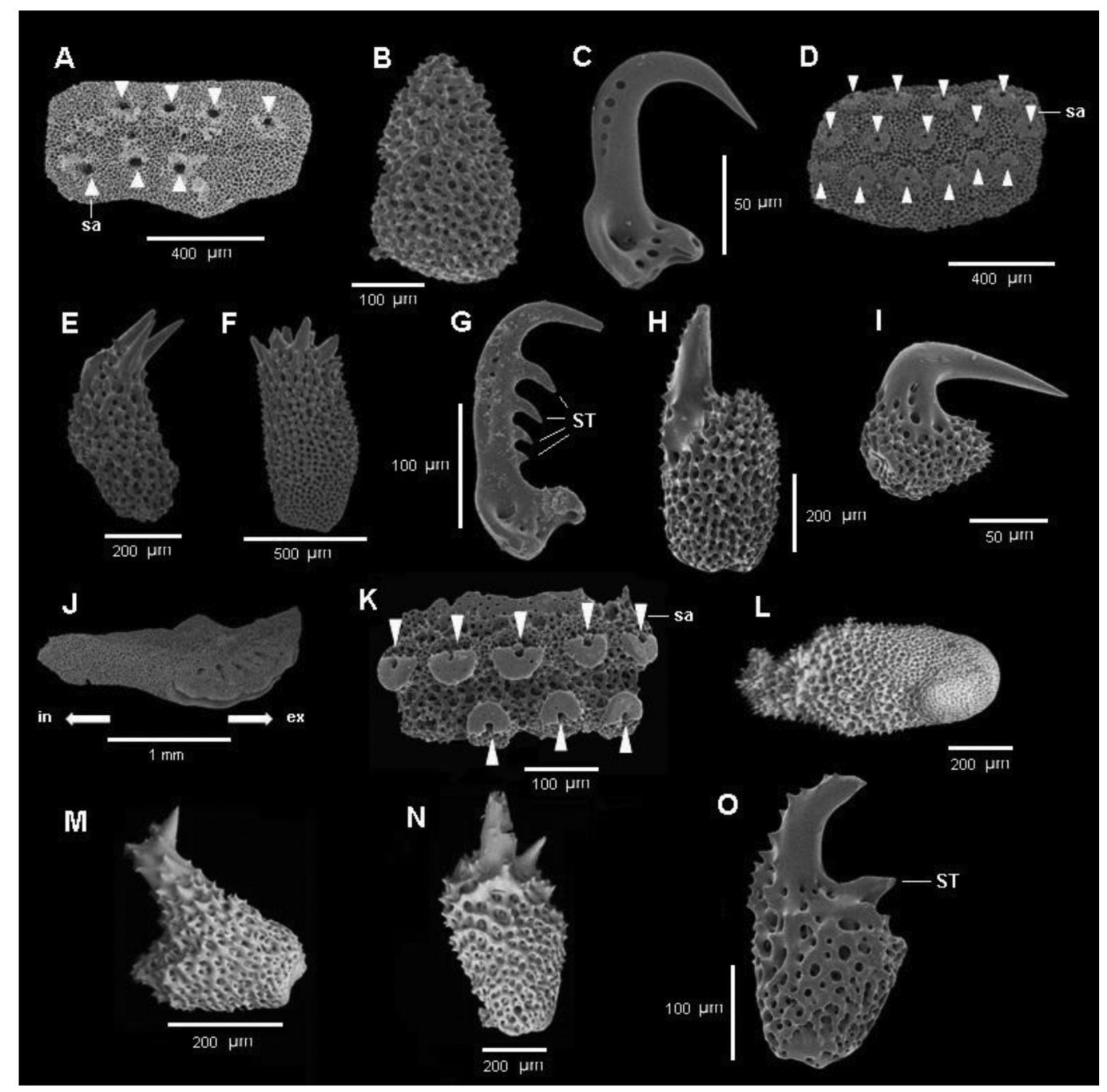

Fig. 7. SEM photographs of external structures of different species of Gorgonocephalidae housed at ICML. Astrodictyum cf. panamense (ICML-UNAM 9822). A. Hooklet-bearing plate. B. Distal dorsal plates found. C. Hook of the arm. Astrogomphus vallatus (ICML-UNAM 3.165.0). D. hooklet-bearing plate. E-F. Arm spines. G. hook of the middle portion of the arm. Astrophyton muricatum (ICML-UNAM 3.165.0). H. Arm spines. I. Hook of the arm. Gorgonocephalus chilensis (ICML-UNAM 3.239.0). J. Ventral plates. K. Hooklet-bearing plate. L-M. Arm spines. N. Arm spine. O. Arm spine from the base of the arm. Abbreviations: ST. secondary tooth. sa. spine articulation.

Diagnosis (Lyman, 1869): the entire aboral side is filled with short and thick spines, arranged in concentric rows, the radial shields have a rough and thorny appearance. Every ramification is covered by a belt of four rows of granules; the oral side of the arms is flat, they have a smooth skin that is uniformly covered by small flat granules, that look like a rugged mosaic. The interradial oral spaces are covered by small, round, and flat granules of different sizes.

Scanning Electron Microscopy: Astrogomphus vallatus presents an elongated slightly curved hooklet, with four secondary teeth, with a narrow well-defined base (Fig. 7G). 


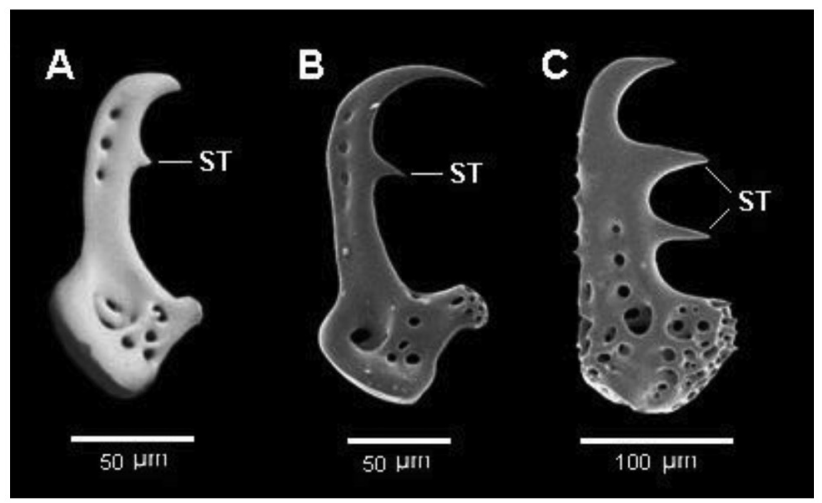

Fig. 8. SEM photographs of the hooks and the arm spine of Gorgonocephalus chilensis (ICML-UNAM 3.239.0) A. Hook from basal portion of the arm. B. Hook from the middle portion of the arm. C. arm spine from the middle portion of arm. Abbreviations: ST. Secondary tooth.

\section{Genus Astrophyton Fleming, 1828}

Diagnosis (Fleming, 1828): ventral disc covered only by skin, five arms divided dicotomically. At the periphery, the genital slit is long, ranging from the peripheral end of the oral shield to the lateral edge of the disc.

\section{Astrophyton muricatum (Lamarck, 1816)}

Fig. 5A, 5B, 5C, 5D, Fig. 7H, 7I.

Euryale muricatum Lamarck 1816: 538. Astrophyton arborescens, Müller \& Troschel, 1842: 124. Astrophyton muricatum.- Müller \& Troschel, 1842: 122; Döderlein, 1911: 7, 18, 53, 108, Fig. 1; Döderlein, 1927: 24, 25.

Diagnosis (Müller \& Troschel, 1842): the radial shields stand out at the aboral side, they exhibit a thin granulation with conic spines that have a sliced tip (Fig. 5A); the arm granulation is thin and dense, covering the entire arm; the first segment of the arms do not have arm spine, only the thinner ramifications have two or three short arm spines. The oral side of the disc is characterized by having a thick arm base with few small and fine granules at the oral interradius, the arms can be exhibit either tubercules or spines.

Scanning Electron Microscopy: Astrophyton muricatum: the spines and hooklets are of two types and easily distinguished; one spine has a rectangular base and a short hooklet (Fig. $7 \mathrm{H}$ ), meanwhile the other is curved with an ovoid base (Fig. 7I).

\section{Genus Gorgonocephalus Leach, 1815}

Diagnosis (Leach, 1815): it presents a convex body with five thick and dichotomic arms, the distal ramifications are thin and more bifurcated. The species have bursal slits at each side of the base of the arm's inferior side.

Gorgonocephalus chilensis (Philippi, 1858)

Fig. 5E, 5F, 5G, 5H, Fig. 7J, 7K, 7L, 7M, $7 \mathrm{~N}, 7 \mathrm{O}$, Fig. $8 \mathrm{~A}, 8 \mathrm{~B}, 8 \mathrm{C}$.

Astrophyton chilense Philippi, 1858: 268. Astrophyton pourtalesi Lyman, 1875: 28. Gorgonocephalus chilensis var. Novaezelandiae Mortensen 1924: 91. Gorgonocephalus chilensis.- Döderlein 1911: 30, 105, Fig. 5; Döderlein, 1927: 30; Monteiro \& Tommasi, 1983: 56, figs. 1-6.

Diagnosis (Philippi, 1858): radial shields protruding; the arms spread five times, and the final ramifications are rosary-shaped, usually every bifurcation is divided again into another segment, but the ramifications are not identical. It has 12 main ramifications, the arms at the base get divided three more times. 
Scanning Electron Microscopy: Gorgonocephalus chilensis has three types of spines and four types of hooklets, three of these hooklets have a secondary tooth, but the shape of the base of them is different (Fig. 7O, 8A, 8B), the fourth hooklet exhibits two secondary teeth and a narrow base (Fig. 8C), the perforations of the hooklets change in number and position (Fig. $8 \mathrm{~A}, 8 \mathrm{~B}, 8 \mathrm{C})$.

\section{DISCUSSION}

There have been published taxonomic lists which include the gorgonocephalids of the Gulf of Mexico and Gulf of California (HernándezHerrejón, 2007; Laguarda-Figueras, Hernández-Herrejón, Solís-Marín, \& Durán-González, 2009) however, they have focused only on external structures. Gorgonocephalids reported in the present study were analyzed using mainly internal taxonomic characteristics; this paper includes two genera and species for the Gulf of California and seven genera and species for the Mexican Caribbean and the Gulf of Mexico.

Asteroporpa (Asteroporpa) annulata is the type species of this genus, it was described by Örsted \& Lütken (1856) in Lütken (1856), this species was collected in the western islands of the Caribbean (West Indies) (Örsted \& Lütken in Lütken, 1856), however, the description based on the specimens collected from these areas was very poor. They mentioned taxonomic characters of disc highlighting the presence of irregular tubercles and rows full of hookletbearing plates in the arms. A. (Asteroporpa) annulata is distinguished from these species: A. (Asteroporpa) australiensis Clark, 1909, A. (A.) pulchra Clark, 1915, A. (A.) affinis Lütken, 1859, for having simple arms, a convex disc and thin arms, thin radial shields with lines of granules, presence of protruding bands surrounding the arms, oral part of the disc very granulated and hooklets present throughout the oral part of the arms.

According to Lyman (1869) and Manso, Gondim, \& Ventura (2014), Astracme mucronata is defined by the following morphological characters: a thick and conspicuous disc, and radial shields with numerous spines found in the aboral interradia. Döderlein (1927) mention that $A$. mucronata can be distinguished from $A$. mediterraneus by the latter spines being present only on the radial shields. We examined eight specimens collected in Yucatan, Mexico, these specimens showed a spine (similar to the disc) on the dorsal side of the arms, present up until the third arm segment, one per segment; according to Manso et al. (2014), these specimens correspond to adult individuals.

Astrocaneum herrerai differs from A. spinosum by having a granule-covered disc, with conical spines arranged in crossed bands at the radial shields; it is also possible to observe ringed arms, each ring posses a hooklet bearing plate with a short and conical spine. Meanwhile, A. spinosum possesses a smooth skin covering the disc (except for the groups of spines located between the radial shields), and the arms possess a group of spines arranged in rows (Lyman, 1875; Clark, 1919).

According to Baker, Okanishi \& Pawson (2018), Astrocyclus somaliensis differs from A. caecilian in having the disk partially covered with more or less continuous, transverse, thin white lines made up of closely packed granules, surrounding the radial shields and partially extending into the inter-shield and interradial areas; this specie was collected in the north-eastern coast of Somalia (Indian Ocean); A. caecilia has been recorded from the Caribbean Sea, Gulf of Mexico, and from northeastern Brazil by Gondim, Días \& Christoffersen (2015).

All the Astrocaneum cf. panamense specimens examined in the present study, exhibited calcareous plates covered with granules and spines in crossed bands on top of their radial shields; the interradial areas have scattered packs of two to three spines; the arms are ringed and at their base, there are fragmented calcareous plates covered with spines. All the previously stated is not mentioned in the original description by Verrill (1867). It is very important to review all these specimens in the near future; it may be a new species of the genus Astrocaneum. 
One of the most relevant contributions of this study is to propose the synonymization of Astrogomphus rudis Verrill, 1899 under Astrogomphus vallatus Lyman, 1869. It is important to mention that this species was reported by Laguarda-Figueras et al. (2009) as Astrochele lymani. However, the material mentioned by the later authors was reviewed, and their taxonomic description does not agree with Verrill (1878), they rather fit with the genus Astrogomphus Lyman, 1869 which is represented by two species $A$. rudis Verrill, 1899 and A. vallatus Lyman, 1869. At the moment of comparing the type material of both species we noticed that the morphological variation was minimal, Verrill (1899) differentiated the species using variations in the disk ornamentation, but both species share the same disk structures, and both species possess the same ventral ornamentation, in the oral side, close to the jaws, there are small "arm spines" distributed in group of five which also cover the entire ventral side of the arms.

This is the first study that describes Astracme mucronata, Astrocaneum herrerai, Astrocaneum spinosum, Astrogomphus vallatus and Gorgonocephalus chilensis external structures (hooks, ventral plates and spines) with providing SEM photographs. Asteroporpa (Asteromoana) muricatopatella and Asteroporpa (Asteromoana) koyoae differ from A. (Asteroporpa) annulata in that the first species has arm hooks with two lateral teeth, while the second species has three lateral teeth of the hooklets located on the basal portion of the ventral arm.

When describing A. somaliensis, Baker et al. (2018) mention the presence of three types of spines and two simple hooks of varying sizes; in the present study it was found that A. caecilia possesses only simple hooks distributed along the arm, these structures have an arched base with three well-defined pores, these hooks ( $A$. caecilia) are smaller than the ones in A. somaliensis.

Ethical statement: authors declare that they all agree with this publication and made significant contributions; that there is no conflict of interest of any kind; and that we followed all pertinent ethical and legal procedures and requirements. All financial sources are fully and clearly stated in the acknowledgements section. A signed document has been filed in the journal archives.

\section{ACKNOWLEDGEMENTS}

We would like to thank Berenit Mendoza (Instituto de Biología [IB], UNAM) and Laura Gómez (ICML, UNAM) for their support taking the SEM photographs; Susana Guzmán (Laboratorio de Microscopía y Fotografía de la Biodiversidad, IB, UNAM) for her guidance provided taking the multifocal photographies; Adam J. Baldinger (Museum of Comparative Zoology, Harvard, USA), for providing photographs of type material; and Alicia DuránGonzález (ICML, UNAM) for her technical support. Our appreciation goes to Carlos A. Conejeros Vargas for preparing the figures that illustrates the present work. To Itzel Rosales, Francisco Márquez (Posgrado en Ciencias del Mar y Limnología, UNAM), and Tania PinedaEnríquez (University of Florida, U.S.A.) for their valuable constructive criticism during the early stages of this work, and to Antonio Tinoco for his reviews, time spent and support shown throughout the development of this study.

\section{RESUMEN}

Lista anotada de la familia Gorgonocephalidae (Echinodermata: Ophiuroidea) de la Colección Nacional de Equinodermos "Dra. Ma. E. Caso M." del Instituto de Ciencias del Mar y Limnología, UNAM

Introducción: El orden Euryalida está formado por ofiuros frágiles con brazos delgados, largos y a veces ramificados. Las especies de la familia Gorgonocephalidae se caracterizan por la presencia de diminutos ganchos en el lado dorsal de sus brazos. Los estudios que refieren especies de la familia Gorgonocephalidae que habitan en aguas mexicanas son escasos. Objetivo: Realizar la revisión taxonómica de dicha familia, reconociendo los caracteres taxonómicos diagnósticos para generar una guía ilustrada de cada una de las especies que se encuentran en la CNE del ICML, UNAM. Métodos: Se recopiló toda la bibliografía especializada de la familia, posteriormente con 
ayuda de fotografías de MEB y multifocal se fotografiaron los especímenes de la CNE para destacar las estructuras de importancia taxonómica. Resultados: se revisaron un total de 193 ejemplares correspondientes a ocho géneros, nueve especies, siendo el género Astrocaneum el de mayor riqueza específica. Conclusiones: Para las especies identificadas en este estudio, para dar una identificación más precisa, se destacaron los caracteres morfológicos forma de los ganchos y forma de las placas de los brazos.

Palabras clave: Estrellas canasta, taxonomía, biodiversidad, mar profundo, México.

\section{REFERENCES}

Baker, A.N. (1980). Euryalinid Ophiuroidea (Echinodermata) from Australia, New Zealland, and the southwest Pacific Ocean. New Zealand Journal of Zoology, $7,11-83$

Baker, A.N., Okanishi, M., \& Pawson, D.L. (2018). Euryalid brittle stars from the International Indian Ocean Expedition 1963-64 (Echinodermata: Ophiuroidea: Euryalida). Zootaxa, 4392(1), 1-27.

Béarez, P., \& Bujard, J.T. (2013). First record of Astrocaneum spinosum (Echinodermata: Ophiuroidea: Gorgonocephalidae) from the Gulf of Guayaquil, tropical eastern Pacific. Marine Biodiversity Records, 6. 1-3.

Manso, C. C, Gondim, I.A., \& Ventura, C.R. (2014). New records of Ophiuroidea (Echinodermata) of the Brazilian coast, with notes on its taxonomy and distribution. Marine Biodiversity Records, 7(1), 1-7.

Clark, A.H. (1919). A new genus and species of multibrachiate ophiuran of the family Gorgonocephalidae from the Caribbean Sea. Proceedings of the United States National Museum, 54(2257), 637-640.

Döderlein, L. (1911). Über japanische und andere Euryalae. Abhandlungen der Bayerischen Akademie der Wissenschaften, 5(2), 1-123.

Döderlein, L. (1927). Indopacifische Euryalae. Abhandlungen der Bayerischen Akademie der Wissenchaften, 31(6), 1-105.

Durán-González, A., Laguarda-Figueras, A., Solís-Marín, F.A., Sánchez-Buitrón, B.E., Ahearn, C.G., \& TorresVega, J. (2005). Equinodermos (Echinodermata) de las aguas mexicanas del Golfo de México. Revista de Biología Tropical, 53 (Supl. 3): 53-68.

Fleming, J. (1828). A history of British animals, exhibiting the descriptive characters and systematical arrangement of the genera and species of quadrupeds, birds, reptiles, fishes, Mollusca, and Radiata of the United Kingdom; including the indigenous, extirpated, and extinct kinds, together with periodical and occasional visitants. Edinburgh, Bell \& Bradfute / London, James Duncan, 1, 565.

Gondim, A.I., Días, T.L.P., \& Manso, C.L.C. (2012). Updated morphological description of Asteroporpa (Asteroporpa) annulata (Eurylida: Gorgonocephalidae) from the Brazilian coast, whit notes on the geographic distribution of the subgenus. Revista de Biología Marina y Oceanografia, 47(1), 141-146.

Gondim, A. I., Días, T.L.P., \& Christoffersen, M.L. (2015). First record of basket stars Astrocyclus caecilia (Lütken, 1856) and Astrophyton muricatum (Lamarck, 1816) (Echinodermata, Ophiuroidea, Euryalida) for the state of Rio Grande do Norte, northeastern Brazil. Check List, 11(1), 1541.

Hendler, G. (1984). The association of Ophiothrix lineata and Callyspongia vaginalis: A brittlestar-sponge cleaning simbiosis? Marine Ecology, 5, 9-27.

Hendler, G. \& J.E. Miller. (1984). Feeding behavior of Asteroporpa annulata, a gorgonocephalid brittlestar with unbranched arms. Bulletin of Marine Science, 34: 449-460.

Hernández-Herrejón, L.A. (2007). Ofiuroideos (Echinodermata: Ophiuroidea) del Golfo de México (Bachelor thesis). Universidad Michoacana de San Nicolás de Hidalgo, México, 1-248.

Hyman, L.H. (1955). The invertebrates: Echinodermata - The coelomate bilateria. New York: McGraw-Hill Book Company.

Laguarda-Figueras, A., Hernández-Herrejón, L.A., SolísMarín, F.A., \& Durán-González, A. (2009). Ofiuroideos del Caribe Mexicano y Golfo de México. México: CONABIO, ICMyL, UNAM, Jíménez Editores.

Lamarck, J.B.M.de. (1816). Histoire naturelle des animaux sans vertèbres. Tome second. Paris: Verdière, $568 \mathrm{pp}$.

Leach, W. E. (1815). The Zoological Miscellany; Being Descriptions of New, or Interesting Animals. R.P. Nodder, London, 2, 1-154.

Ljungman, A.V. (1867). Ophiuroidea viventia huc usque cognita enumerata. Öfversigt af Kongelige Vetenskapsakademiens Forhandlingar Stockholm, 1866, 303-336.

Lütken, C.F. (1856). Bidrag til kundskab om Slangestjernerne. II. Oversigt over de vestindiske Ophiurer. Videnskabelige Meddelelser fra Dansk Naturhistorisk Förening i Kjobenhavn 1856, 7, 1-19.

Lyman, T. (1869). Preliminary report on the Ophiuridae and Astrophytidae dredged in deep water between Cuba and Florida Reef. Bulletin of the Museum of Comparative Zoology, 1, 309-354. 
Lyman, T. (1875). Zoological Results of the Hassler Expedition. 2. Ophiuridae and Astrophytidae. Illustrated catalogue of the Museum of Comparative Zoology of Harvard College, 8(2), 1-34.

Lyman, T. (1882). Report on the Ophiuroidea dredged by H. M. S. "Challenger" during the years 1873-1876. Report on the Scientific Results of Voyage of H.M.S. Challenger during the years 1873-76. Zoology, 5(14): $1-386$.

Monteiro, A.M.G., \& Tommasi, L.R. (1983). Ophiuroidea das regiões Antártica e Subantártica: 2. Variação em Gorgonocephalus chilensis (Philippi) (Echinodermata, Ophiuroidea, Gorgonocephalidae). Boletim do Instituto Oceanográfico, 32(1): 55-61.

Mortensen, T. (1924). Echinoderms of New Zealand and the Auckland-Campbell Islands. II. Ophiuroidea. Papers from Dr Th. Mortensen's Pacific Expedition (Vid. Medd. Dansk Naturh. Foren. 77), 20, 91-177.

Müller J., \& Troschel, F.H. (1842). System der Asteriden. Mit Swölf Kupfertafeln. 12, 1-134.

O’Hara, T. D., Hugall, A.F., Thuy, B., Stöhr, S., \& Martynov, A.V. (2018). Restructuring higher taxonomy using broad-scale phylogenomics: the living Ophiuroidea. Molecular phylogenetics and evolution, 107, 415-430.

Okanishi, M., \& Fujita, T. (2011). Two new species of the subgenus Asteroporpa (Asteromoana) (Ophiuroidea: Euryalida: Gorgonocephalidae) from Japan. Zootaxa, 2751(25-39), 16

Okanishi, M. (2016). Ophiuroidea (Echinodermata): systematics and Japanese fauna. In: Motokawa, M. \& Kajihara, H. (Eds.), Species diversity of animals in Japan. Springer Japan, Tokyo, pp. 651-678.

Philippi, A. (1858). Beschreibungen einiger neuer Seesterne aus dem Meere von Chiloe. Archiv für Naturgeschichte, 24(1), 264-268.
Piepenburg, D. (2000). Arctic brittle stars (Echinodermata: Ophiuroidea). Oceanography and Marine Biology: An Annual Review, 38, 189-256.

Pomory, C.M. (2007). Key to the common shallow-water brittle stars (Echinodermata: Ophiuroidea) of the Gulf of Mexico and Caribbean Sea. Caribbean Journal of Science, 10, 1-42.

Solís-Marín, F.A., Laguarda-Figueras, A., \& Honey-Escandón, M. (2014). Biodiversidad de equinodermos (Echinodermata) en México. Revista Mexicana de Biodiversidad, 85, 441- 449.

Stöhr, S., O’Hara, T. \& Thuy, B. (2012). Global Diversity of brittle stars (Echonodermata: Ophiuroidea). PloS ONE, 7(3), 1-14

Stöhr, S. (2015). Gorgonocephalidae Ljungman, 1867. In S. Stöhr, T. O’Hara \& B. Thuy (Eds.), World Ophiuroidea database. World Register of Marine Species. Retrieved from http://www.marinespecies.org/aphia. php? $\mathrm{p}=$ taxdetails \& id $=123203$

Tommasi, L.R. (1970). Os Ofiuróides Recentes de Brasil e de Regioes Vizinhas. Contribuições Avulsas do Instituti Oceanográfico, Universidade de São Paulo, Série Oceanografia Biológica, 20, 1-146.

Verrill, A.E. (1867). Notes on Radiata in the museum of Yale College with descriptions of new genera and species. No. 2. Notes on the echinoderms of Panama and the west coast of America, with descriptions of a new genus. Transactions of the Connecticut Academy of Arts and Science, 1(2), 251-322.

Verrill, A.E. (1899). VII. North American Ophiuroidea. I. Revision of certain families and genera of west Indian Ophiurans. II. A faunal catalogue of the knows species of west Indian ophiurans. Transactions of the Connecticut Academy of Arts and Science, 10(7), 301-386. 